\title{
The Edo period created the sound material-cycle society
}

\author{
Masaaki Hosomi ${ }^{1}$
}

Published online: 16 October 2015

(c) Springer-Verlag Berlin Heidelberg 2015

According to the environmental planning in Japan, a sustainable society is when such key features as low-carbon economy, biodiversity, and close-looped material cycle are intertwined under a safe and robust civil infrastructure. Many experts assert that the seeds for these key features of sustainable society were firmly planted in Japan in the Edo period (CE 1603-1868). I herewith illustrate some accomplishments of the Edo period. This is a good reference for sustainability discussion in Japan.

The Edo period was the era when an internally selfsufficient economy thrived because no resources and energies were allowed to be imported as a result of the national isolation imposed by the Tokugawa Shogunate. In this period of isolation, foods and energies were acquired by domestic production of plants. In other words, the material, foods, and energy systems were based on solar energy. In the first 100 years of the Edo period, the population in Japan increased from ca. 12 million to ca. 30 million due to an increase in agricultural areas, resulting in increased food production. Nevertheless, for the rest of the Edo period, the population remained unchanged. This is because (1) cold seasons prevailed worldwide and agricultural production reached saturation, and (2) consecutively, starvation appeared as a scourge. Eventually, however, the sustainable society with the population of 30 million thrived on solar energy for the remaining 150 years of the Edo period. During this Edo period, the Edo culture for popular entertainment flourished with the emergence of Kabuki, Japanese-type puppets, wood block prints, and so

Masaaki Hosomi

hosomi@cc.tuat.ac.jp

1 Tokyo University of Agriculture and Technology, Tokyo, Japan on. The educational system of Terakoya, i.e., a private elementary school system was also developed, contributing to an increase in literary rates above $50 \%$ for common people and of even $100 \%$ for samurai warriors. These rates were, at that time, the highest levels in the world.

Main fuels in the Edo period were firewood and charcoal. Because the cold ashes have alkaline nature, they were widely used for not only ameliorants for acid soils but also detergents and shampoos after the ashes were dissolved in water. There was even an occupation called ash buyer, whose task was to mediate effective utilization of ash wastes. Human feces in this material-cycle society were used as precious fertilizers for farmers. It was an article of commerce, fetching revenues to a seller. A landlord running a row house earned money as much from feces as from house rent. According to paleography, prices for feces were dependent on economic affluence of a family. There was also an occupation for carrying night soils. More importantly, honey buckets were used as honey toilets at that time. This bucket was a simple fermentation vessel with a lid on the top, embedded into an excavated pit next to a field. The Edo Shogunate instructed people living in urbanized areas to set a large toilet tank to effectively keep a large amount of feces. Subsequently, feces, partially fermented in the toilet tank, were transferred to farmers in suburbia by either a ship or bullock carts, and again fermented in a vessel before their application to a field. The addition of rice straws facilitated more anaerobic fermentation and to kill ascarids and pathogens, leading to the creation safe fertilizers. Finally, material recycle/reuse/repair was widely practiced, for example, for making handmade kimonos and umbrellas. The Edo society saw little unemployment at the time. 